DOI: $10.25140 / 2411-5363-2018-4(14)-216-222$

\author{
Peter Marcinko, Ondrej Juruš
}

\title{
AN EXPERIMENTAL WORKPLACE WITH SCARA ROBOT
}

Urgency of the research. Interest in this subject is aroused because, in the available sources, this kinematic structure is the least documented, even though it is required in certain applications (fast assembly of small parts,...).

Target setting. The main goal was to design a workplace with a Scara robot. This workplace is used by the student to verify their theoretical knowledge gained from lectures in practice. They can try programming the robot, but also work with the camera system.

Actual scientific researches and issues analysis. In 1961, (USA) the first industrial robot Unimate was put into the industrial practise for General Motors for welding of vehicle body. Since this industrial robot deployment has gone on for many years and many changes have been made in the field of industrial robotics in terms of mechanical properties and industrial robot control systems, taking account the requirements of applications in technical practise.

Uninvestigated parts of general matters defining. This article focuses on analysis of the proposed of workplace with robot of kinematic structure Scara and parts of workplace.

The research objective. The aim of the research was to design and assembly workplace with robot Scara with camera system by Omron.

The statement of basic materials. The analysis consists of basic information about kinematic structure of Scara robots. Based on this knowledge the $3 D$ model of workplace and parts is described.

Conclusions. The robot workplace with the Scara robot and the Omron F150 camera system is designed for students to verify the theoretical knowledge gained from the lectures in practice. At the same time, the workplace can be used to solve and verify the knowledge in solving various projects related to the use of CCTV systems in a robotic workplace. Due to longterm use of the workplace in the educational process, where students were able to intervene in software and hardware equipment, several parts of the workplace were damaged. The next step is to upgrade the entire workplace.

Key words: kinematics scara; camera system; workplace.

Fig.: 7. References: 7.

Problem definition. In 1961, (USA) the first industrial robot Unimate was put into the industrial practise for General Motors for welding of vehicle body. Since this industrial robot deployment has gone on for many years and many changes have been made in the field of industrial robotics in terms of mechanical properties and industrial robot control systems, taking account the requirements of applications in technical practise.

At present, the development of industrial robots accentuate emphasis on the reliability of the robot in operation, on the quality level as well as on the dynamics (speed) of the robot, but also on the accuracy and repeatability of the movements. Technological and handling qualifications depend on the input (load, end load, ...) and output (accuracy and repeatability, track accuracy, ...) parameters. These parameters can be used as a requirement for robot development, diagnosis and testing.

The current trend in the field of robotics use robots structures to construct so-called bounded spatial mechanism built on two kinematic structures either serial or parallel. Parts of these kinematic structures are kinematic couples either translational (R) or rotational $(T)$. TTT, RTT, RRT and RRR are standard robot design structures. From these kinematic structures each specifies the robot properties.

In the applications of robot technology in the production and non-production processes in automation, the demands on the properties of industrial robots (demands for efficiency, safety, reliability, ...) in applications where they are deployed are increasing. The variety of these systems requires new ratings of robots deployed in production and non-production applications, based on practical and theoretical interconnection of knowledge of kinematic structures, theoretical possibilities and operational properties, identification and monitoring of robot parameters, methods of monitoring and measurement of robots.

The issue of assessing the technological and manipulative characteristics of industrial robots requires closer interest. The work deal with by a kinematic structure called Scara, which is a variation of the RRT structure. The meaning of SCARA stands for Selective Compliance Assembly Robot Arm.

(C) Marcinko P., Juruš O., 2018 
TECHNICAL SCIENCES AND TECHNOLOGIES

Type of kinematic structure Scara. Scara robots, based on an analysis of available literature on their use in practise, are mainly used as assembly robots or handling robots, but there are also applications in other technologies, for example an application of surface coatings (spraying) or for other materials (glue, adhesives etc.), palletizing and depaletisation. Several types of these robots are shown on Fig. 1.
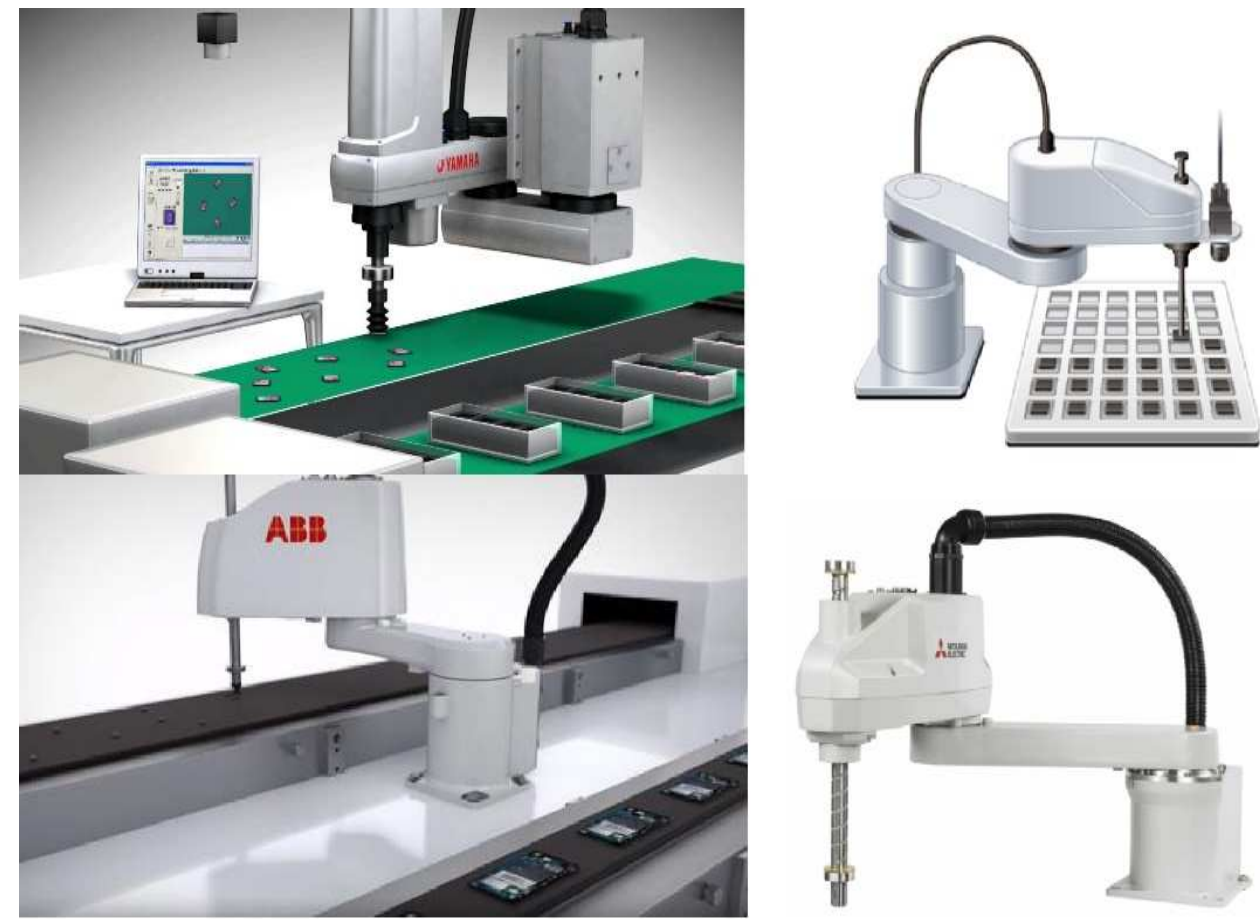

Fig. 1. Scara robots

The robot was built at the University of Yamanashi, led by Professor Hiroshi Makino (1978). Kinematics Scara belongs to RRT mechanical structures. The Scara kinematics was first introduced in 1981 by NEC as the new concept of a mounting robot. The positioning mechanism is categorized (as a subsystem of action mechanism) as a serial arrangement of two rotational (R) and one translational (T) kinematic pair, Fig 2. Kinematics Scara is designed for selected applications, especially in the category of assembly operations. The workspace is a cylindrical solid.
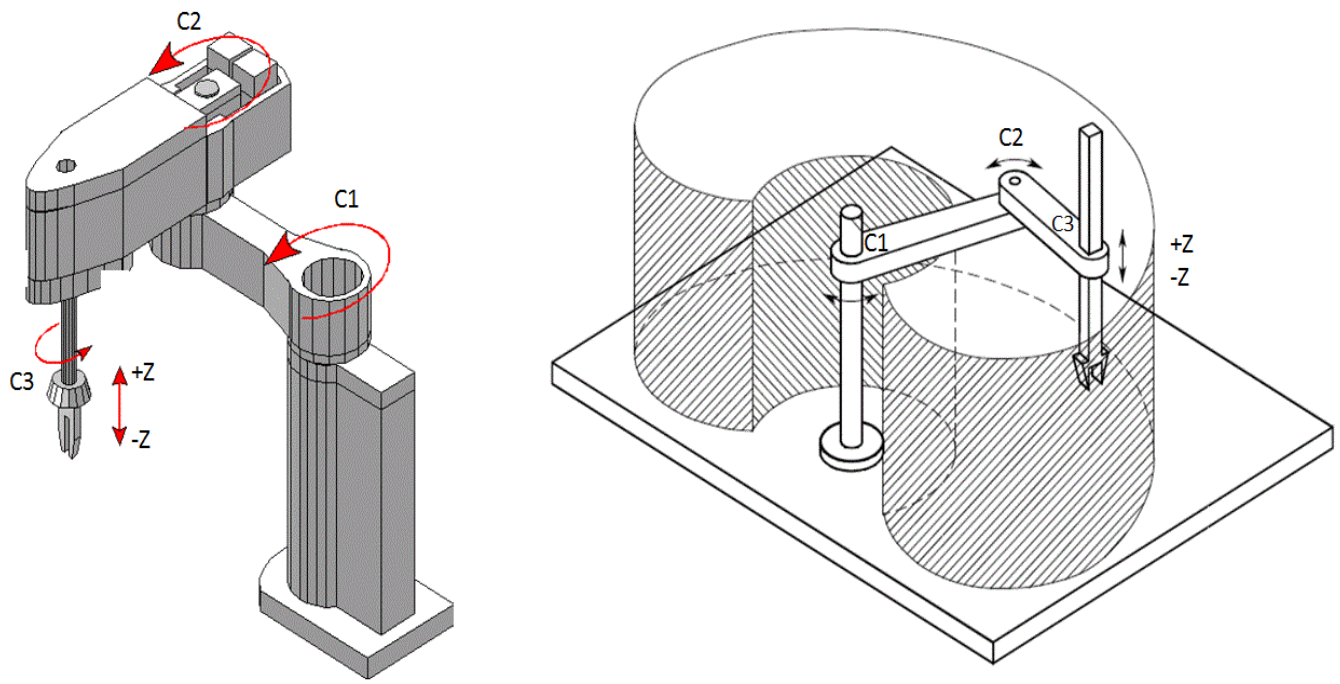

Fig. 2. Structure and manipulation workplace 
TECHNICAL SCIENCES AND TECHNOLOGIES

Kinematics Scara can be described and expressed in comparison with another structure in terms of its typical features, which appear in its applicability. As a comparison of Scara kinematics with TTT type kinematics, speed parameters linked to one-time position repeatability can be mentioned, Fig. 3.

Scara kinematics robots are typical of having lower stiffness compared to the TTT mechanical structure. This is due to the fact that all the joints of the mechanical structure are located at the ends of the arms, i.e. the proportion of matter increases without support, which necessarily leads to greater deflections and consequently to greater inaccuracies. Consequently, Scara robots have a worse load balance, their payload is lower than that of robots with TTT structure. With higher load, the speed of movement decreases.

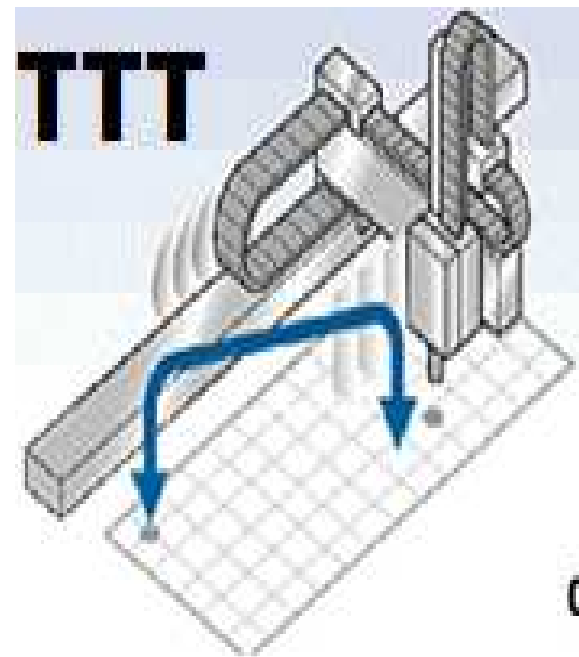

\section{0,95 sec}

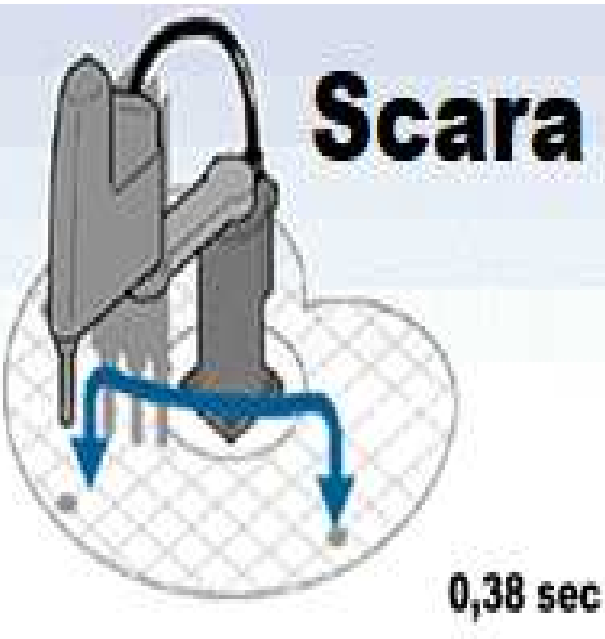

Fig. 3. Comparison kinematics structure TTT and Scara

The construction of the Scara robot guarantees its strength in the vertical direction, while at the same time it offers high flexibility in the horizontal plane. When applying Scara robots in dusty or corrosive environments, it is possible to seal the joints hermetically and create specific design solution for the "clean" environment. Fixing Scara robots affects their application potential. Together with the size of the arms, their arrangement and range of movements, they affect the robots handling capabilities, but also the dimensions and shape of the workspace. In general, it can be stated that by using a suitable assembling method, it is possible to guarantee a sufficiently compact and simple form of installation, Fig. 4.
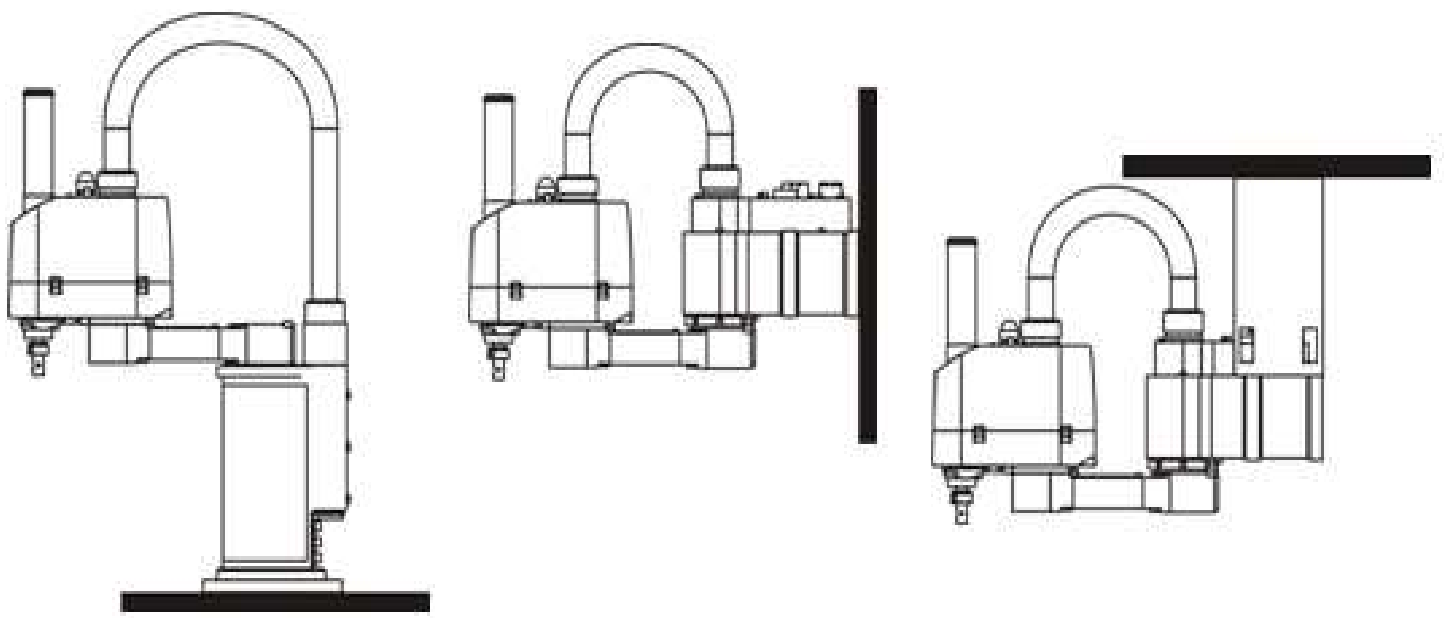

Fig. 4. Positioning of Scara 
TECHNICAL SCIENCES AND TECHNOLOGIES

Characteristic and parts of Scara. Scara robots are among the fast industrial robots, performing precise assembly work with high flexibility in motion. They have the most frequent four degrees of freedom (DOF). The robotic arm of Scara functions principally as a human arm, so it performs human-like movements (shoulder, elbow and wrist axes). Shoulders are constructed with serial kinematics. The first and second axes of movement are usually rotating, allowing the arm to move horizontally. The third and fourth axes of motion are realized by a screw ball. This allows translational and rotational movement. However, Scara has a wrist motion restriction. This causes the wrist to rotate but cannot tilt. Restriction is an advantage in several types of assembly and palletizing applications. Fig. 5. shows the main components from which the Scara industrial robot is composed.

Characteristic features:

- relatively simple design,

- high stiffness,

- very high accuracy,

- high speed,

- small dimensions,

- high service life and reliability,

- lower maintenance costs.

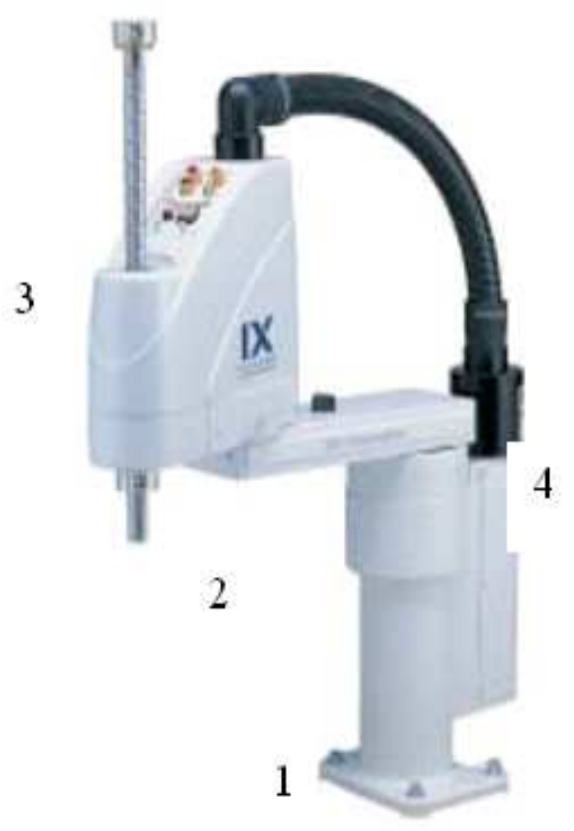

Fig. 5. Main parts of robot Scara

An experimental workplace. The development of production systems equipment has shifted from classic sensor components to robots with 3D camera systems. This is in particular because approaches are insufficient to meet the new requirements for manipulating, grasping or measuring some parameters. Camera sensors are currently an important element of robot equipment for expanding its peripheral capabilities. At present, research based on a $3 \mathrm{D}$ vision and three-dimensional modelling is one of the industries that are the main directions in robotics.

Palette objects can enter a process chaotically arranged, partially oriented or precisely oriented. The first and second cases require that the workplace be equipped with either an orientation device using the various known principles of achieving a given information, such as the use center of gravity, mechanical obstacles etc. or equipping robots with sensors to analyse $2 \mathrm{D}$ and $3 \mathrm{D}$ scenes. 
In general, cameras for product quality control are generally used in industry. The check is carried out by comparing the shapes and geometric characteristics of the manufactured parts with the standard components. These cameras are sometimes inserted during the calibration of the cameras. Another industry application of cameras is to control the progress of technological processes. It belongs here, for example: continuous inspection of machine welding using special cameras. This check is carried out during welding and allows real-time correction of the welding settings of the machine that the welding performs to achieve the optimum welding setting over the entire length. Undoubtedly the progressive trend of deploying camera systems in the industry (and laser scanners) is the ability to capture objects of various shapes and sizes and import them into CAD systems using special software that translates a recorded object into a compatible 3D model.

The development of production systems equipment has shifted from classic sensor components to robots with 3D camera systems. This is in particular because classical approaches are insufficient to meet the new requirements for manipulating, grasping or measuring some parameters. Experimental workplace with robot Scara and camera system, Fig. 6.

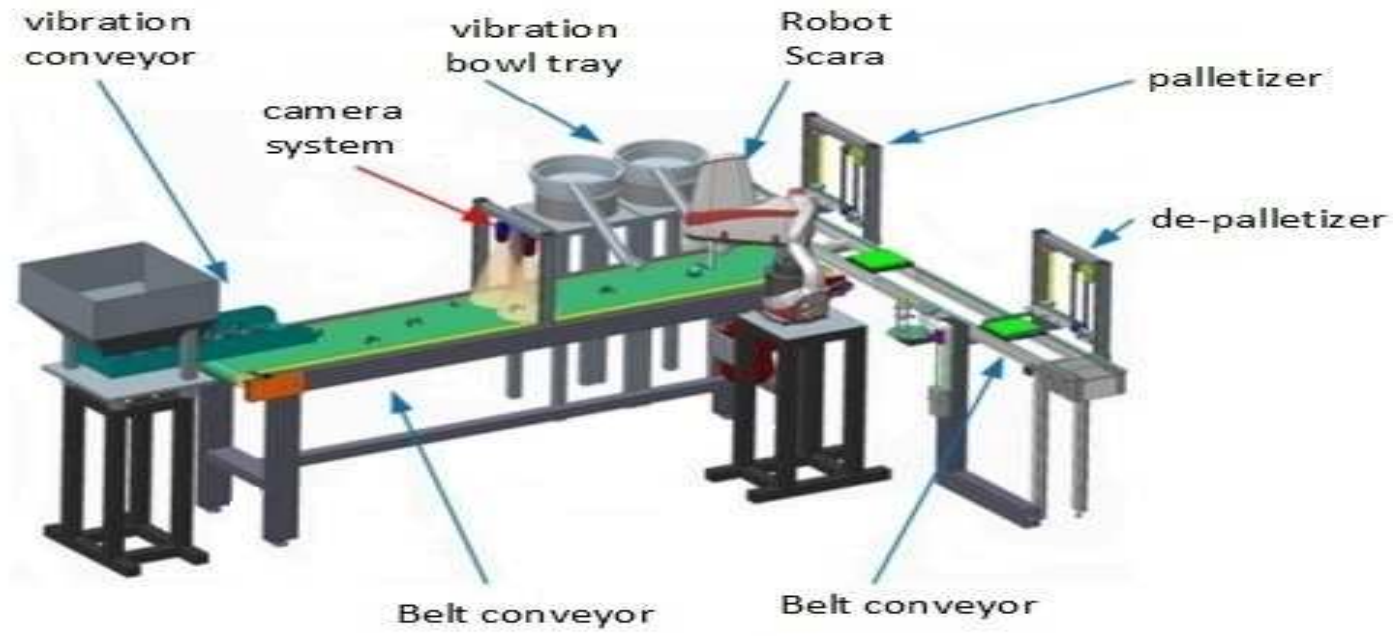

Fig. 6. An experimental workplace

This workplace is composed of several parts:

- vibration conveyor,

- camera system,

- vibration bowl tray,

- robot Scara,

- palletizer,

- de-palletizer,

- belt conveyors.

The real workplace is fitted with the Scara Yamaha YK600X with QRCX control system and the Omron F150-3 camera system. Full control of the workplace is provided by two Omron PLC system CP1H and CP1E. The connection of the camera system to the PLC CP1H controls the PLC CP1L via the RS232C system. The control unit is realized by a touch panel, where it is possible to select from two modes - manual and automatic. The pallet loading is solved using an output conveyor with a palletizing and depalletizing unit. 


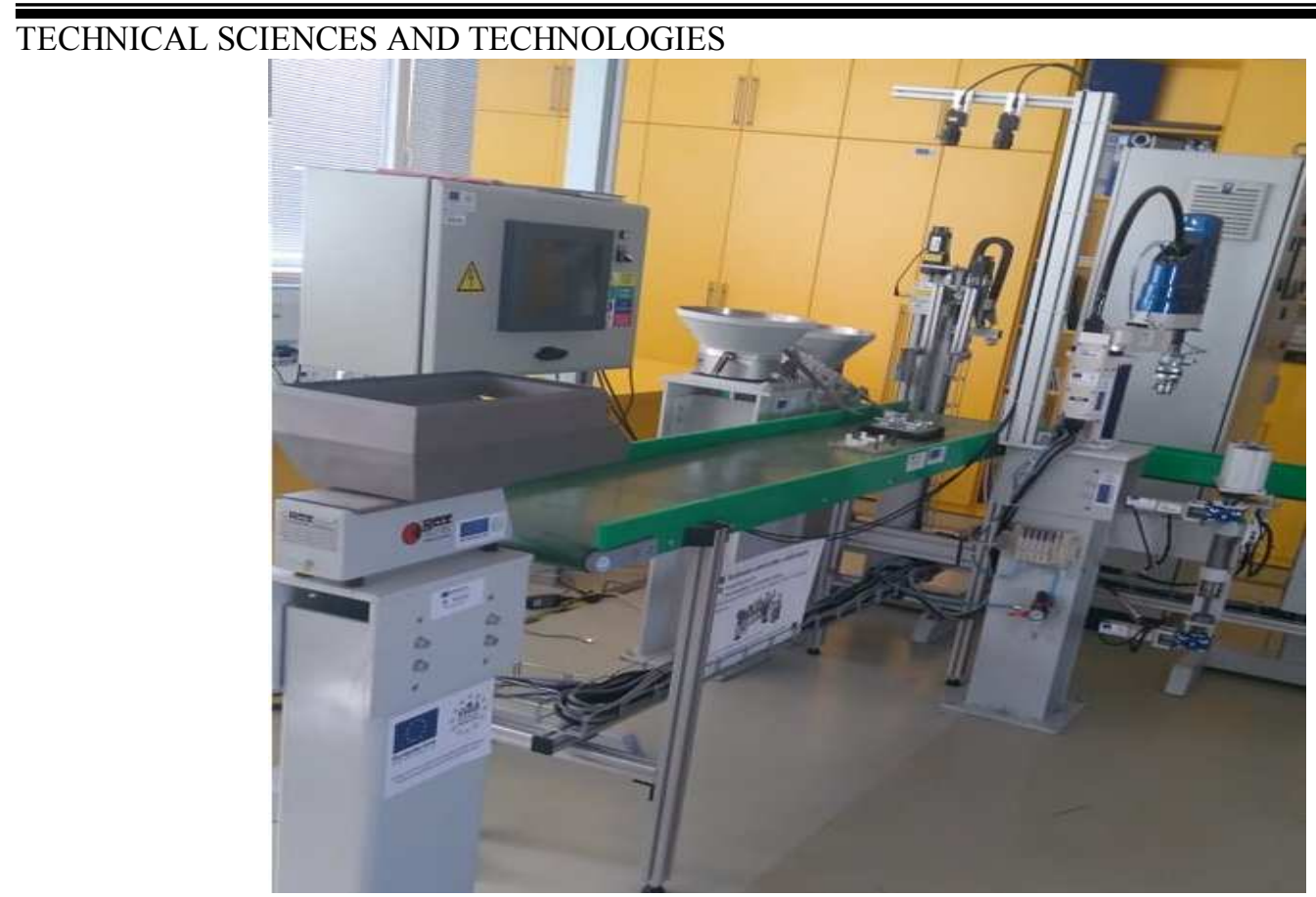

Fig. 7. An experimental workplace

Conclusions. The robot workplace with the Scara robot and the Omron F150 camera system is designed for students to verify the theoretical knowledge gained from the lectures in practice. At the same time, the workplace can be used to solve and verify the knowledge in solving various projects related to the use of CCTV systems in a robotic workplace. Due to long-term use of the workplace in the educational process, where students were able to intervene in software and hardware equipment, several parts of the workplace were damaged. The next step is to upgrade the entire workplace.

\section{Acknowledgements}

This contribution is the result of the project implementation: Aplikovaný výskum systémov inteligentnej manipulácie priemyselných robotov $\mathrm{s}$ neorientovanými 3D objektmi, (ITMS:26220220164), supported by the Research \& Development operational Program funded by the ERDF.

\section{References}

1. Základy priemyselnej robotiky - Scara roboty. Retrieved from http://dailyautomation.sk/scararoboty.

2. Buda, J., Kováć, M. “Projektovanie a prevádzka robotizovaných systémov, Alfa Bratislava, Bratislava 1990, ISBN 80-05-00680-2.

3. Elektrické pohony ako súčast' mechatronických systémov. Retrieved from https://www.atpjournal.sk/buxus/docs/casopisy/atp_2010/pdf/atp-2010-01-34.pdf.

4. Chivarov, N., Galabov, V.: Kinematics of SCARA Robots, In: Problems of Engineering Cybernetics And Robotics, Bulgarian Academy of Science Sofia, Sofia 2018, pp. 51-59.

5. Baláž, V., Vagaš, M., Rusnák, R.: Zvyšovanie inteligencie paletizačno - montážnych robotických buniek na báze CCD kamier, Trends and Innovative Approaches in Business Processes "2015", Vol. 18.

6. Kamerové systémy. Retrieved from https://www.limasoft.cz/omron/pdf/PGB24_Vision_CZ01_ 0305.pdf.

7. Yamaha YK600XGL. Retrived from https:/global.yamaha-motor.com/business/robot/ lineup/ykxg/middle/pdf/index/YK600XGL_E_0707.pdf. 
УДК 004.896

TECHNICAL SCIENCES AND TECHNOLOGIES

\section{Петер Мариинко, Ондрей Юруш \\ ЕКСПЕРИМЕНТАЛЬНЕ РОБОЧЕ МІСЦЕ 3 РОБОТОМ SCARA}

Актуальність теми дослідження. Інтерес до иієё теми викликаний тим, щэо в доступних джерелах ичя кінематична структура є наймени документованою, хоча вона потрібна в певних програмах (ивидке збирання дрібних деталей тощо).

Постановка проблеми. Основною метою було спроектувати робоче місие з роботом Sсага. Це робоче місие використовується студентом для перевірки своїх теоретичних знань, отриманих на лекціях на практиці. Вони можуть спробувати програмувати робота, а також прачювати з системою технічного зору.

Аналіз останніх досліджень $і$ публікацій. У 1961 рочі (США) периий промисловий робот Uпітате був введений в промислову практику для General Motors для зварювання кузова автомобіля. Після використання промислового робота протягом багатьох років було зроблено багато змін у галузі промислової робототехніки з погяду механічних властивостей і систем управління промисловим роботом з урахуванням вимог застосування в технічній практиці.

Виділення недосліджених частин загальної проблеми. Ця стаття присвячена аналізу пропонованого робочого місия з роботом кінематичної структури Sсага і окремих частин робочого місия.

Постановка завдання. Метою дослідження було проектування та складання робочого місия з роботом Sсага із системою технічного зору на базі камер від Oтron.

Виклад основного матеріалу. Аналіз складається з основної інформації про кінематичну структуру роботів Scara. На підставі иих знань описана тривимірна модель робочого місия та його частин.

Висновки відповідно до статmі. Робоче місие робота з роботом Sсага і системою технічного зору га основі камер Oттоп F150 призначене для студентів, щоб перевірити теоретичні знання, отримані на практичних заняттях. Водночас робоче місие може використовуватися для вирішення й перевірки знань при виконанні різних проектів, пов'язаних із використанням систем відеоспостереження на роботизованому робочому місиі. У зв'язку з довгостроковим використанням робочого місия в навчальному процесі, коли учні могли втручатися в програмне й апаратне обладнання, деякі частини робочого місия були пошкоджені. Наступним кроком є оновлення всього робочого місия.

Ключові слова: кінематика скара; система камер; робоче місце.

Рис.: 7. Бібл.: 7.

Peter Marcinko - PhD student Technical University of Kosice, Department of Robotics, Komenskeho Park 8, 042 00 Kosice, Slovakia.

E-mail: peter.marcinko@tuke.sk

Scopus Author ID: 57200138054

Ondrej Juruš - PhD student, Department of robotic, Technical University of Kosice (Park Komenského 8., 04001 Košice, Slovakia).

E-mail: ondrj.jurus@tuke.sk

Scopus Author ID: 57201321175

Marcinko, P., Juruš, O. (2018). An experimental workplace with scara robot. Technical sciences and technologies, 4 (14), $216-222$. 